\title{
The Discovery and Geology of the Timber Creek Kimberlites, Northern Territory, Australia
}

\author{
Berryman, A.K. ${ }^{1}$, Stiefenhofer, J. $^{2}$, Shee, S.R. ${ }^{1}$, and Wyatt, B.A. ${ }^{1}$ \\ 1. Stockdale Prospecting Limited, 60 Wilson Street South Yarra Vic. 3141 Australia. \\ 2. Anglo American Res. Labs., PO Box 106, Crown Mines, 2025 South Africa.
}

A review of diamond discoveries across Australia highlights the Kimberley Block in Western Australia and the North Australian Craton as areas of significant interest. While this is partly a function of the level of exploration conducted in these areas, the discovery of diamondiferous intrusives confirms the prospectivity of both regions. As a result, Stockdale Prospecting Limited (SPL), a subsidiary of De Beers, has spent considerable effort exploring the North Australian Craton and has discovered kimberlites in the Roper River region of the McArthur Basin, and kimberlites in the Timber Creek region.

The Timber Creek kimberlites were discovered by SPL between 1991 and 1993, and are located $10 \mathrm{~km}$ due south of the township of Timber Creek, which in turn lies $350 \mathrm{~km}$ south of Darwin, in Australia's Northern Territory (Figure 1). They are the first kimberlites discovered within the Victoria River Basin and intrude early to mid Proterozoic limestones and dolomites (Sweet, 1977). The nearest known diamondiferous intrusive is the Argyle Lamproite, some $250 \mathrm{~km}$ to the south west. The Victoria River Basin forms part of the Sturt Block (Traves, 1955), which in turn is distinguished by the presence of undeformed Proterozoic rocks surrounded by highly deformed, metamorphosed and intrusive rocks, such as the Halls Creek Orogen to the west (Sweet, 1977). Although the extent of the Sturt Block has never been constrained in the east, the work of Shaw et al (1995) suggests that it may extend beneath most of the Wiso Basin. Shaw (op cit.) consider the tectonic setting of the Timber Creek area to be part of a covered Proterozoic crustal element characterised by a subdued magnetic response.

Figure 1: Location : Timber Creek Kimberlites

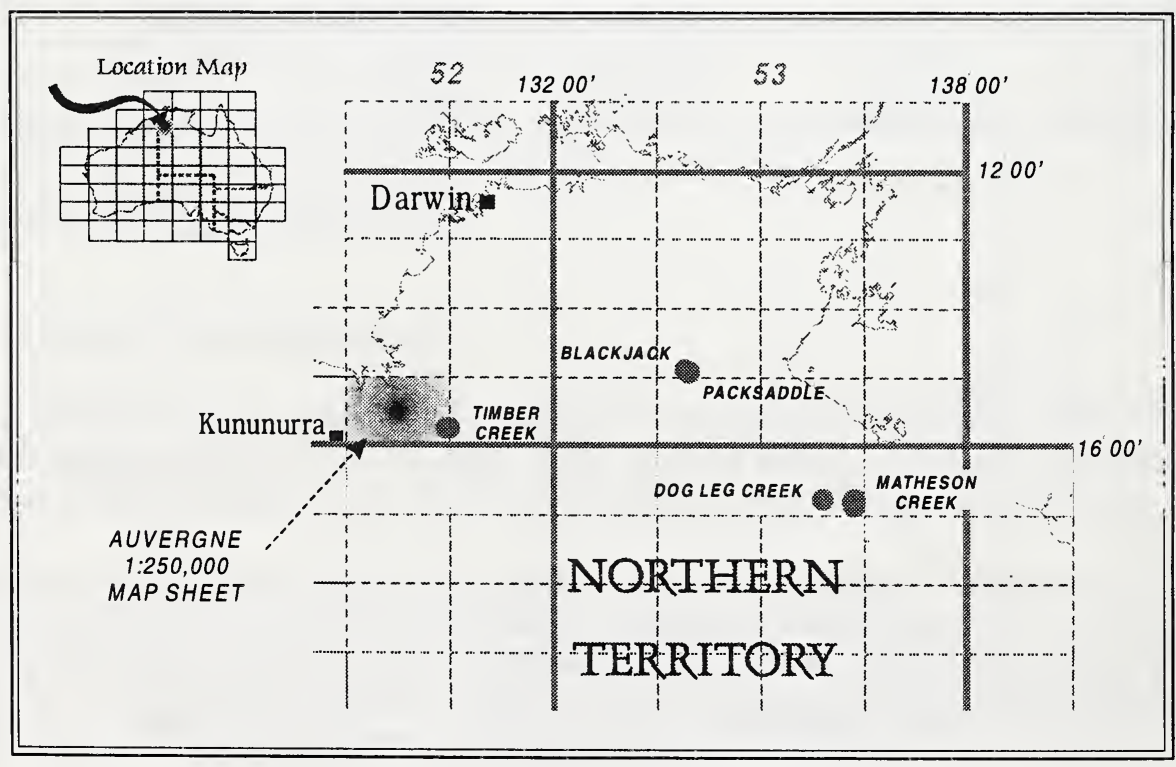


Five kimberlites were discovered by conventional heavy mineral sampling and subsequent drilling. Sample results suggest that an additional number of small undiscovered kimberlites exist in the immediate area. The first kimberlite discovered (TC-01) is a small blow, less than $50 \mathrm{~m}$ in diameter, which is associated with an outcropping dyke. The small exposure is heavily silicified and brecciated. The remaining four kimberlites (TC-02 to 05) are dykes less than 2 metres wide which strike at $280^{\circ}$ to $310^{\circ}$. Kimberlites TC-01, 02,03 and 04 all have minor surface exposure. The TC-04 is actually a small dyke swarm, containing mineralogically variable kimberlite.

The kimberlites have no significant airborne or ground magnetic response (due partly at least to their size), and no anomalous TM satellite image response. An airborne EM (Dighem) survey also failed to highlight the five kimberlites.

Chromian spinel and diamond were the only kimberlitic indicator minerals found during the prospecting phase. Diamonds were also recovered from surface samples near TC-01 and TC04. Neither ilmenite nor pyrope garnet was found. The heavy mineral abundance of spinels from each kimberlite is proportional to the percentage of diamond inclusion type chromites, and also the number of diamonds recovered from the rock. Varying proportions of corona textured spinels are present in all five kimberlites. Typical microprobe analyses of chromites from TC-01 are plotted in Figure 2. Proton Probe trace element analyses of the spinels (Griffin, 1993) indicate that many have characteristics of Group 1 kimberlites. In some chromites $\mathrm{ZnO}$ and/or $\mathrm{MnO}$ has replaced $\mathrm{MgO}$ possibly due to low- $\mathrm{T}$ metamorphic reequilibration.

Figure 2
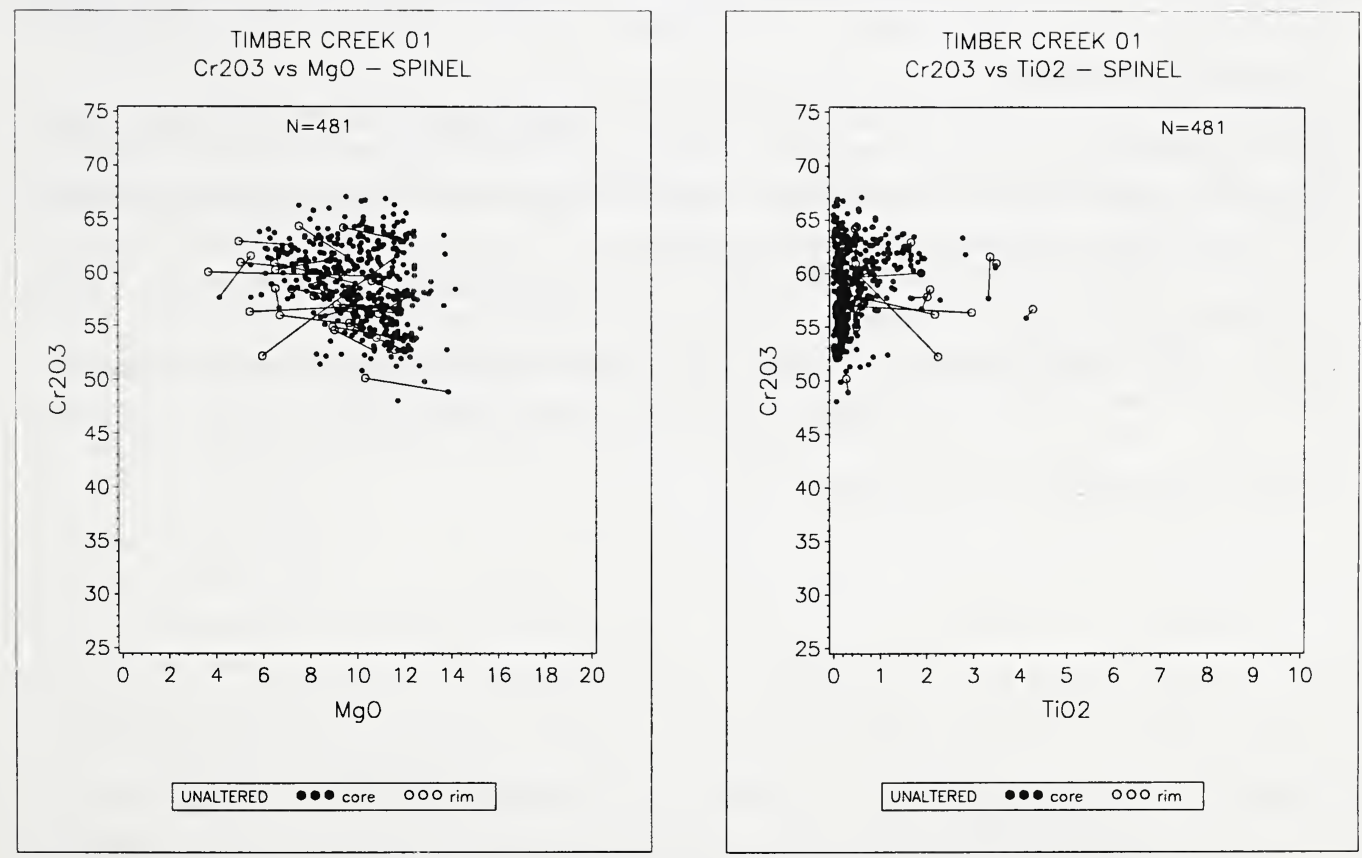

Only hypabyssal facies kimberlite is present, represented by porphyritic and highly silicified brecciated material. Mineralogically, they are classified as macrocrystic probable Group 1 phlogopite - monticellite kimberlites. Due to the extremely altered and silicified nature of the rocks, petrographic classifications are tentative. Groundmass minerals are generally easier to identify than the macrocrystic grains. Most of the kimberlites contain colourless phenocrysts 
and rare macrocryst pseudomorphs, thought to be altered olivine and mica (phlogopite). TC-01 in particular is dominated by silicified and iron stained country rock fragments (shales and siltstones) and pseudomorphs. Probable groundmass minerals include phlogopite, monticellite, apatite, perovskite and occasional euhedral opaque spinel.

Geochemically, the kimberlites are complex and variable. The severe silicification and carbonation of the rocks has subdued some of the more typical "kimberlitic" geochemical responses. Elements such as $\mathrm{Nb}, \mathrm{Cr}, \mathrm{Ni}, \mathrm{Ti}$ and $\mathrm{Zr}$ are generally elevated relative to local levels in the area.

The weathered nature of the kimberlites has made age determination difficult. Mantle zircons collected from a bulk sample adjacent to TC-01 give a U/Pb SHRIMP date of $1462+/-53 \mathrm{Ma}$ (Armstrong, 1995). However, zircon fission track data from the same bulk sample suggest a possible age of $1038+/-66 \mathrm{Ma}$ (Green, 1996). The latter result may have been effected by reequilibration due to regional uplift (D. Phillips, personal comm.).

Diamonds have been recovered from kimberlites 01, 02 and 04. Diamond recovery has not been attempted for the other two kimberlites, although chromian spinel chemistry would suggest they have either very low diamond grades or are barren. Preliminary analysis of TC-01 suggests that it has a grade in excess of 100 CPHT. The diamonds are generally yellow or brown in colour, often displaying green radiation spots, particularly within deep cracks or ruts. Most of the diamonds are rounded dodecahedral crystals, which rarely show growth remnants, suggesting an advanced state of resorption.

\section{References}

Armstrong, R.A., 1995, Ion microprobe (SHRIMP) U-Pb zircon dating of kimberlitic zircons from sample X 9150: Res. School of Earth Sci., Aust. Nat. Uni., confidential report to Stockdale Prospecting Ltd.

Green, P.F., 1996, Fission Track Dating of kimberlitic zircon grains: Geotrack Report number 621 (unpublished)

Griffin, W.L., 1993, Proton Probe Analysis of Spinels from the Timber Creek area: CSIRO Division of Exploration Geoscience (unpublished).

Shaw, R.D., Wellman, P., Gunn, P., Whitaker, A.J., Tarlowski, C., and Morse, M.P., 1955, Australian Crustal Elements Map: AGSO Research Newsletter 23.

Sweet, I.P., 1977, The Precambrian Geology of the Victoria River Region: Northern Territory. Bureau of Mineral Resources, Geology and Geophysics, Bulletin 168.

Traves, D.M., 1955, The geology of the Ord-Victoria Region, Northern Australia: Bureau of Mineral Resources, Australia, Bulletin 27 